\title{
ECOTOXICOLOGICAL EFFECT OF MESOTRIONE ON ENZYME ACTIVITY AND MICROBIAL COMMUNITY IN AGRICULTURAL SOILS
}

\author{
SUN, Y. B. ${ }^{1,2}-$ WANG, L. ${ }^{1,2}-$ XU, Y. M. ${ }^{1,2^{*}}-$ LIANG, X. F. ${ }^{1,2}-$ ZHENG, S. N. ${ }^{3 *}$ \\ ${ }^{I}$ Key Laboratory of Agro-Environmental Pollution Prevention and Control, Ministry of \\ Agriculture and Rural Affairs, Tianjin 300191, China \\ ${ }^{2}$ Tianjin Key Laboratory of Agro-environment and Agro-product Safety, Agro-Environmental \\ Protection Institute, Ministry of Agriculture and Rural Affairs, Tianjin 300191, China \\ ${ }^{3}$ Rural Energy \& Environment Agency, Ministry of Agriculture and Rural Affairs, Beijing \\ 100125, China \\ ${ }^{*}$ Corresponding authors \\ e-mail:ymxu1999@126.com, zhengshunan1234@163.com; phone: +86-22-2361-8061; fax: \\ +86-22-2361-8060 \\ (Received $3^{\text {rd }}$ Dec 2019; accepted $26^{\text {th }}$ Mar 2020)
}

\begin{abstract}
Multiple experiments were performed to evaluate the ecotoxicological effect of mesotrione on soil enzymatic activity, functional diversity, and genetic microbial biodiversity. The results showed that catalase and invertase activity initially increased with higher mesotrione concentration and then declined slightly. However, urease activity experienced a $11.9-23.2 \%$ reduction in comparison to control soil. The average well-color development (AWCD) was positively affected by the mesotrione treatment, the amount of carbohydrate, amino acid, and phenolic acid increased by 1.7-2.1, 1.1-1.6, and 1.7-2.5 times, respectively, when compared with the blank treatment. However, the utilization of carboxylic and acid amine was prohibited after applying $50-100 \mathrm{mg} \mathrm{kg}^{-1}$ and $20-100 \mathrm{mg} \mathrm{kg}^{-1}$ mesotrione. Denaturing gradient gel electrophoresis (DGGE) analysis showed that the shift in the bacterial community structure for different mesotrione treatments can be mainly attributed to an increment in band intensity, while the dissimilarity in the bacterial genetic structure decreased with increasing mesotrione content in the soil. Sequencing and phylogenetic analyses showed that the four bands in the denaturing gradient gel electrophoresis results were closely related to Bacillus subterraneus, Clostridium sp., and Bacillus sp. Obtained results show that abuse of mesotrione may pose a potential risk for soil microbial functioning.

Keywords: mesotrione, Biolog EcoPlates, denaturing gradient gel electrophoresis, eco-environmental impact
\end{abstract}

\section{Introduction}

Soil microbes are fundamental components of a soil's ecosystem playing an important role in many metabolic processes, e.g. the biogeochemical cycling of nutrients, decomposition of organic matter, formation of structural and hydrological properties, and various other biological-physical-chemical processes in the soil (Hu et al., 2011; Liu et al., 2015). Microorganisms can also serve as environmental bioindicators of quality due to their rapid and sensitive response to small environmental disturbances (Zhang et al., 2010; Cycoń et al., 2013b; Gryta et al., 2014). Thus, the microbial properties of the soil, and particularly those related to the diversity and activity of the soil's microbial communities, can be a most useful predictor of the fluctuation in soil health (Zhang et al., 2010; Chen et al., 2014; Allegrini et al., 2015). Soil enzyme also plays an important role in the microbial soil ecology by catalyzing various reactions, including those involved in the decomposition of organic residues and 
nutrient cycling in soil-plant systems (Bhattacharyya et al., 2008; Sun et al., 2013a; Giacometti et al., 2014). In general, microbial activity and soil enzyme activity are usually influenced by various soil management practices, e.g. crop rotation, mulching, tillage, and the application of fertilizers and herbicides (Johnsen et al., 2001; Hua et al., 2009; Lupwayi et al., 2010). Therefore, these can all be used as potential indicators of microbial activity, soil fertility, and land quality (Ciarkowska et al., 2014).

Mesotrione [2-(4-methylsulfonyl-2-nitrobenzoyl)-1,3-cyclohexanedione] is a triketone herbicide that has recently been registered for the pre- and post-emergence control of annual broadleaved weeds in maize fields, and constitutes a replacement for atrazine (Sun et al., 2013b; Pose-Juan et al., 2015). Armel et al. (2009) reported that a dose equal to $235 \mathrm{~g}$ ai ha ${ }^{-1}$ was required to provide effective ( $\left.\geq 80 \%\right)$ control of some common weeds (lamb's quarters, smooth pigweed, and common ragweed). Vyn et al. (2006) documented successful control $(\geq 90 \%)$ of another Amaranthus species (Amaranthus tuberculatus var. rubis) at mesotrione doses of 175 (pre-emergence) and $100 \mathrm{~g}$ ai ha ${ }^{-1}$ (post-emergence). However, our previous studies found that the adsorption isotherms of mesotrione fit well into first-order and Freundlich equations. The hysteresis indices in phaeozem and red soil indicated that it had weak-moderate soil retention properties (Sun et al., 2015) and its degradation time (DT 50 ) varies from 6 to $34 \mathrm{~d}$ (Crouzet et al., 2010). Therefore, the continuous and extensive use of the herbicides would pose side-effects on the function and fertility of agricultural soils. A few studies have attempted to determine the effects of mesotrione on the nitrogen cycle, enzyme activity, and microbes in soil (Crouzet et al., 2010, 2013; Cycoń et al., 2013a; Pose-Juan et al., 2015). Crouzet et al. (2010) found that mesotrione applied at a dose of $0.45 \mathrm{mg} \mathrm{kg}^{-1}$ did not have any effect on the substrate-induced respiration, regardless of the post-treatment exposure time. However, higher doses (45 and $450 \mathrm{mg} \mathrm{kg}^{-1}$ ) of mesotrione induced significant increases. Similarly, mesotrione had a strong negative impact on soil chlorophyll concentration and cyanobacterial genetic structure and diversity when its content was up to $450 \mathrm{mg} \mathrm{kg}^{-1}$ (Crouzet et al., 2013).

Non-targeted effects of herbicides on soil microorganisms can reduce microbial diversity but increase functional diversity. There may even be a tendency towards reversible stimulatory/inhibitory effects on microbial community structure and activity (Zabaloy et al., 2010; Pose-Juan et al., 2015). It has been reported that herbicides are adsorbed by organic matter in the soil to form bound or recalcitrant states, which, in turn, reduces the possibility of microbial attack (Crouzet et al., 2010). This might also account for the insignificant effect (or masking) of the impact of herbicides on the activity of enzymes (Cai et al., 2015). These effects depend on the herbicide's properties and environmental chemical behavior, soil type, environmental conditions, and functioning of the soil's microorganisms (Lupwayi et al., 2010; Pose-Juan et al., 2015). It is therefore essential to assess the ecological and environmental impact of newly marketed xenobiotics such as mesotrione in China. Unfortunately, information on the environmental impact of mesotrione in the soil (on enzyme activity and diversity of the microbial communities) is lacking. Therefore, the experiments reported here are the first aimed at extending our knowledge of these aspects. The objectives of the present study are to determine mesotrione's effects on: (1) soil enzymatic activity (via a microcosm approach), (2) functional diversity (using the Biolog method), and (3) genetic microbial biodiversity (using a method based on denaturing gradient gel electrophoresis, DGGE). 


\section{Materials and methods}

\section{Test chemicals}

The mesotrione $\left(\mathrm{C}_{14} \mathrm{H}_{13} \mathrm{NO}_{7} \mathrm{~S}\right)$ was purchased from Sigma-Aldrich (St. Louis, MO, USA) in the form of dispersible granules (high performance liquid chromatography (HPLC) grade with a purity of $99.9 \%$ ). The solubility of mesotrione in water increases with $\mathrm{pH}$ value (being 2.2, 15, and $22 \mathrm{~g} \mathrm{~L}^{-1}$ at $\mathrm{pH} 4.8,6.9$, and 9.0, respectively), and the stability stable to hydrolysis is at $\mathrm{pH} 4-9$ (pKa 3.12).

\section{Experimental design and treatment regime}

The present research was conducted in Agro-environmental Protection Institute, Ministry of Agriculture and Rural Affairs, China. $10 \mathrm{~kg}$ soil samples were collected from 0-20 $\mathrm{cm}$ layer of agricultural fields in Changsha City, China $\left(28^{\circ} 03^{\prime} \mathrm{N}\right.$ and $\left.113^{\circ} 11^{\prime} \mathrm{E}\right)$ and then passed through a 20 mesh sieve for the analysis of physical and chemical fraction. The basic characteristics of this ferralsol soil are that it consists of $44.9 \%$ clay, $8.6 \%$ silt, and $46.5 \%$ sand. The amount of organic matter, total $\mathrm{N}, \mathrm{pH}$, available $\mathrm{P}$, and available $\mathrm{K}$ equate to $1.03 \%, 0.84 \mathrm{~g} \mathrm{~kg}^{-1}, 4.92,3.95 \mathrm{mg} \mathrm{kg}^{-1}$, and $40 \mathrm{mg} \mathrm{kg}^{-1}$, respectively.

Weighed amounts $(500 \mathrm{~g})$ of dried and sieved soil were placed in plastic pots and preincubated under controlled experimental conditions for two weeks. The effect of mesotrione on soil enzymatic activity and the microbial communities was investigated using 4 different doses of $0,20,50$ and $100 \mathrm{mg} \mathrm{kg}^{-1}$, respectively. After mixing thoroughly, the treated soils were incubated in a dark experimental chamber at $21 \pm 1{ }^{\circ} \mathrm{C}$ for $30 \mathrm{~d}$, and changed randomly every week. To make moisture conditions comparable to those in the field, the soil's moisture content was adjusted to $40 \%$ of the maximum (saturated) value. This was subsequently maintained throughout the experiment by weighing the microcosms on a weekly basis and adding sterile distilled water as needed.

\section{Enzyme assay}

Catalase activity was assayed according to the method used by Sun et al. (2015). The measured enzymatic activities were then calculated and expressed using units of $\mathrm{mg} \mathrm{g}^{-1} \mathrm{~h}^{-1}$. Urease activity was measured using the method adopted by Chen et al. (2014) with slight modification. The enzymatic activity was calculated and expressed as $\mathrm{NH}_{4}-\mathrm{N} \mathrm{mg} \mathrm{g}^{-1} \mathrm{~h}^{-1}$. Invertase activity was determined using an $8 \%$ sucrose solution as substrate and incubation at $37^{\circ} \mathrm{C}$ for $24 \mathrm{~h}$, after which the glucose produced was measured at $508 \mathrm{~nm}$ using a colorimetric method. The enzymatic activity was finally expressed as $\mathrm{mg} \mathrm{g}^{-1} \mathrm{~h}^{-1}$ (Kandeler et al., 1999).

\section{Microbiological analyses}

\section{Functional diversity determination}

The community-level physiological profiles (CLPPs) of the bacteria in the soil samples were evaluated using a Biolog EcoPlate ${ }^{\mathrm{TM}}$ system (Biolog Inc., CA, USA). This procedure tests the ability of a microbial community to utilize different carbon substrates contained in microplates. The soil samples $(10 \mathrm{~g})$ were mixed with $0.85 \%$ $\mathrm{NaCl}$ and then shaken for $1 \mathrm{~h}$. After this time, aliquots $(150 \mu \mathrm{L})$ of the soil suspension were added to the Biolog EcoPlate ${ }^{\circledR}$ microplates containing 31 sole carbon sources and 
a water control. The plates were incubated at $24^{\circ} \mathrm{C}$ in the dark. Color development in each well was recorded in terms of the optical density (OD) at $590 \mathrm{~nm}$ (color development + turbidity) and $750 \mathrm{~nm}$ (turbidity). This was carried out after inoculation and at $24 \mathrm{~h}$ intervals for $168 \mathrm{~h}$ using a microplate reader (Victor TM X5 multilabel plate reader, PerkinElmer) (Osem et al., 2007; Cycoń et al., 2013b). Negative readings, after correction, were adjusted to zero.

\section{Analysis of the microbial structure diversity}

The total bacterial DNA in the test soils was extracted and purified according to previously published methods (Qing et al., 2007; Huang et al., 2008). It was then amplified via PCR using forward primer F $_{357}$ (5'-CCT ACG GGA GGC AGC AG-3') and reverse primer $\mathrm{R}_{518}$ (5'-ATT ACC GCG GCT GCT GG-3'). As for the forward primer, a 40-base GC clamp (5'-CGC CCG CCG CGC GCG GCG GGC GGG GCG GGG GCA CGG GGG G-3') was added to the 5' end to stabilize the melting behavior of the DNA fragments. The gradient concentrations used in the denaturing gradient gel electrophoresis (DGGE) analysis ranged from 35\% to $65 \%$ for bacterial DNA. Initial denaturation was carried out at $94^{\circ} \mathrm{C}$ for $4 \mathrm{~min}$. Amplification was carried out using 35 cycles including denaturation at $94^{\circ} \mathrm{C}$ for $1 \mathrm{~min}$, annealing at $55^{\circ} \mathrm{C}$ for $1 \mathrm{~min}$, and DNA extension at $72^{\circ} \mathrm{C}$ for $1 \mathrm{~min}$, followed by a final extension cycle at $72^{\circ} \mathrm{C}$ for $10 \mathrm{~min}$.

PCR products from the soils were characterized using a DGGE run on a vertical acrylamide gel in a D-Code System (Bio-Rad Laboratories Ltd., Hertfordshire, UK). The DGGE gels were made from $8 \%(\mathrm{w} / \mathrm{v})$ acrylamide stock solutions (37.5:1 of acrylamide:bis acrylamide solution) containing $100 \%$ denaturant $\left(7 \mathrm{~mol} \mathrm{~L}^{-1}\right.$ urea and $40 \%(\mathrm{v} / \mathrm{v})$ formamide). The DGGE bands of interest were cut from the gel and soaked overnight at $4{ }^{\circ} \mathrm{C}$ in $50 \mu \mathrm{L}$ TAE buffer $\left(10 \mathrm{mmol} \mathrm{L}^{-1}\right.$ tris-acetate, $\mathrm{pH} 7.5,1 \mathrm{mmol} \mathrm{L}^{-1}$ EDTA). The gel was stained for $15 \mathrm{~min}$ with ethidium bromide after electrophoresis and visualized using a UV transilluminator table using a gel documentation system (Bio-Rad, Hercules, CA, USA).

The 16S rDNA gene sequences of the excised DGGE bands were compared with existing sequences in the GenBank database using the BLAST 2.0 program (http:/www.ncbi.nlm.nih.gov/BLAST) to determine the nearest matches. The GenBank sequences were added to the data set for CLUSTAL W multiple sequence alignment and the phylogenetic distance tree was constructed using MEGA 4.0.

\section{Statistical analysis}

All of the experiments were replicated three times. The means and standard deviations (SDs) of the replicated data were calculated using Microsoft Office Excel 2010. One-way analysis of variance was performed using the SPSS (v10.0) software package. When a significant difference $(P<0.05$ or $P<0.01)$ was observed between the treatments, multiple comparisons were made by performing an LSD test. Principal component analysis (PCA) was used to identify distinct differences in the soil microbial community functions under different mesotrione treatments.

\section{Average well-color development}

The average well-color development (AWCD) can be calculated to reflect the solecarbon utilization of the soil microorganisms via Equation 1: 


$$
A W C D=\sum\left(C_{i}-R\right) / 31
$$

where $C_{i}$ is OD in each carbon source well and $R$ is OD of the control. When $C_{i}-R<0$, the value is considered to be zero.

\section{Microbial functional diversity indices}

Several diversity indices can be calculated using the equations that follow. These are referred to as the Shannon index $(H)$, Simpson index $(D)$, Shannon evenness index $(E)$, McIntosh index $(U)$, and Dice index $\left(C_{S}\right)$, and are given by Equations 2-6:

$$
\begin{gathered}
H=-\sum P_{i} \ln \left(P_{i}\right) \\
D=1-\sum P_{i}^{2} \\
E=\frac{H}{H_{\max }}=\frac{H}{\ln S_{i}} \\
U=\left(\sum N_{i}^{2}\right)^{1 / 2} \\
C_{s}=\frac{2 j}{a+b}
\end{gathered}
$$

In these expressions, $N_{i}$ is the metabolic activity on each substrate, $P_{i}$ is the ratio of $n_{i}$ to the sum of the activities on all substrates, $S_{i}$ is the natural logarithm of the number of species, $j$ is the number of bands common to samples $\mathrm{A}$ and $\mathrm{B}$, and $a$ and $b$ are the number of bands in samples A and B, respectively.

\section{Results and discussion}

\section{Soil enzymatic activity}

In the present study, the catalase activity initially increased and then declined as the amount of mesotrione increased. Under the application of 20 and $50 \mathrm{mg} \mathrm{kg}^{-1}$ mesotrione, the increase was amounted to $11.2 \%$ and $12.6 \%$, respectively (Fig. 1). However, catalase activity fell by $2.7 \%$ when the concentration of mesotrione was increased up to $100 \mathrm{mg} \mathrm{kg}^{-1}$. There was no significant difference in catalase activity across the $20-100 \mathrm{mg} \mathrm{kg}^{-1}$ mesotrione treatment range $(P>0.05)$. Similar results have been obtained by Baćmaga et al. (2014), who found that metazachlor applied at doses of $6.7-106.7 \mathrm{mg} \mathrm{kg}{ }^{-1}$ stimulated the activity of catalase in the range of $7.5-92.5 \%$. Moreover, Liu (2000) reported that imidacloprid can also stimulate catalase activity, and that the higher the concentration used, the stronger the observed effect on soil catalase for imidacloprid doses in the range $1-40 \mathrm{mg} \mathrm{kg}^{-1}$. However, there was no obvious effect on catalase activity after application of 0.5 to $50 \mathrm{mg} \mathrm{kg}^{-1}$ of acetamiprid for 14 days (Yao et al., 2006). 


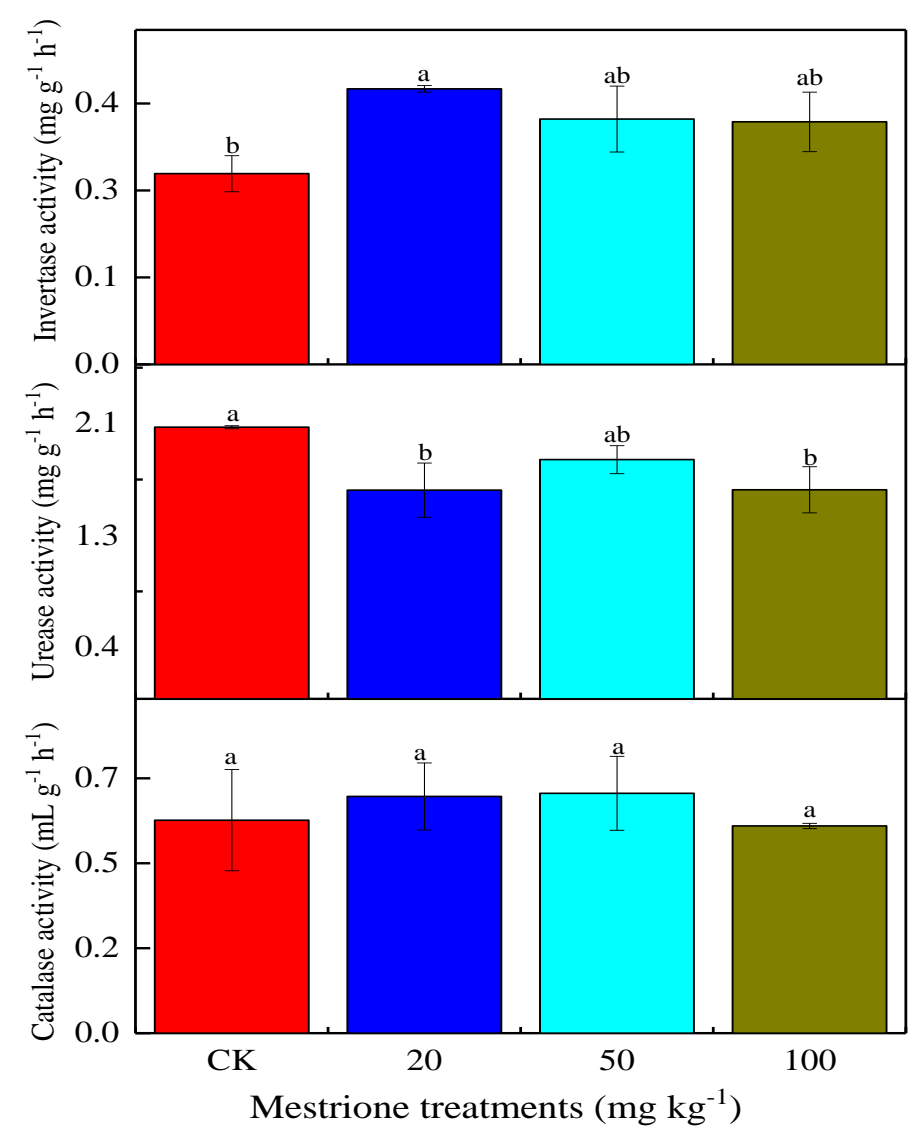

Figure 1. Effects of mesotrione on soil enzyme activities. Letters above the bar diagram refer to the difference at significance level $P<0.05$ among different treatments of mesotrione. The same as below

Urease, which involves in the hydrolysis of urea-type substrates, is an enzyme that quickly responds to changes in the soil environment (Yao et al., 2006). Furthermore, contamination of soil with mesotrione has a destructive influence on the activity of urease. The application of mesotrione caused a 11.9-23.2\% reduction in urease activity compared with control soil (Fig. 1), and amending the soil with 20 and $100 \mathrm{mg} \mathrm{kg}^{-1}$ mesotrione resulted in a significant decrease in urease activity $(P<0.05)$. Results similar to ours concerning the inhibitory effects of herbicides on urease activity have been reported by Baćmaga et al. (2014) who investigated metazachlor and by Sukul (2006) who tested metalaxyl. In turn, Yao et al. (2006), who investigated the ecotoxicology of the herbicide acetamiprid, did not detect any obvious influence on urease activity.

Another enzyme used in assays evaluating the quality of soil is invertase, which is involved in the hydrolysis of sucrose to glucose and fructose. Invertase is more efficient than other enzymes in reflecting soil fertility and biological activity levels (Cang et al., 2009). Fig. 1 exhibits the promotion effect of mesotrione on invertase activity in the soil, which increased at first and then decreases with increasing concentration. It was, however, always $27.1-44.4 \%$ greater than that of the control soil over the $20-100 \mathrm{mg} \mathrm{kg}^{-1}$ mesotrione range. In particular, there was a significant increase using $20 \mathrm{mg} \mathrm{kg}^{-1}$ of mesotrione $(P<0.05)$. Positive effects of buprofezin and acephate on invertase had already been noted by Raju and Venkateswarlu (2014). 
The results above clearly indicate that soil enzyme activity differs in sensitivity upon application of herbicide. Ye et al. (2003) likewise found that mefenacet strongly prohibited soil dehydrogenase activity in a concentration-dependent manner, but stimulated phosphatase activity. Indeed, both significantly positive and negative, as well as neutral, responses have been recorded compared to untreated soils (Floch et al., 2011; Baćmaga et al., 2014). Herbicides may change enzyme protein or interact directly by binding with protein-active groups which subsequently affects their catalytic activity. Another possible reason is that a herbicide may indirectly affect soil enzyme activity by acting on soil microorganisms (Johnsen et al., 2001; Floch et al., 2011; Baćmaga et al., 2014; Jacobsen and Hjelmsø, 2014). Baćmaga et al. (2014) demonstrated that in soil contaminated with excessive quantities of metazachlor there are significant effects on the biochemical activity of the soil (with correlation coefficients that are negative). In another report, no significant differences $(P>0.05)$ were found in enzyme activity in treated soil compared to a control in the initial 2 weeks, while enzyme activity was stimulated from the third week on (Yao et al., 2006). Moreover, the influence of pesticide on soil was generally a long-term process and closely related to the soil's characteristics (Yao et al., 2006).

\section{Microbial community substrate utilization profile}

Color development in the Biolog EcoPlates was analyzed to qualitatively and quantitatively assess the community-level physiological profile of the microbe communities in treated soils (Osem et al., 2007; Gryta et al., 2014). The average wellcolor development in the Biolog generally followed similar patterns (Fig. 2a), i.e. an apparent lag phase was experienced during the first $48 \mathrm{~h}$. After this time, the AWCD values increased rapidly with incubation time for all treatments which is attributable to more rapid bacterial growth taking place. The period selected for metabolic activity analysis was $120 \mathrm{~h}$ as this period corresponded to the occurrence of the largest AWCD change. The slope of the AWCD curve at this time can be used to represent the average metabolic activity of a microbial sample (Kong et al., 2013). Thus, the slopes of the AWCD curves after $120 \mathrm{~h}$ were selected for use in the metabolic activity analysis. The analysis of the variation in AWCD in the stressed soils over the incubation time (during the period $0-120 \mathrm{~h}$ ), showed that the AWCD values using $20-100 \mathrm{mg} \mathrm{kg}^{-1}$ of mesotrione were all higher than those of the control. Strong oxidation of the supplied carbon sources (high AWCD) usually reflects an increase in bacterial density (Loranger-Merciris et al., 2006). A possible reason for this might be that soil microbes tolerate and adapt to the herbicide after repeated applications, and/or degrade the herbicide as a source of carbon and energy (Yao et al., 2006; Xu et al., 2014). However, after an incubation time of $168 \mathrm{~h}$, the AWCD values decreased with an increase in mesotrione, and a dose-effect relationship could be discerned.

The substrate utilization patterns currently established via the Biolog Ecoplates can be used to determine the changes in the functioning of the soil microbial communities (Floch et al., 2011). As shown in Fig. 2b, there were remarkable differences in the substrate utilization profiles of the mesotrione treated soil samples. Carbon source metabolism by the microbial population decreased in the following order: polymer > amino acid > carbohydrate > phenolic acid > acid amine > carboxylic acid. This suggested that the carboxylic acid could be more easily utilized by the microbes subjected to the different mesotrione treatments. Although the variation in the carbon sources appeared to be irregular under the series of mesotrione treatments, the increase 
in the amount and rate of carbohydrate, amino acid, and phenolic acid utilization observed in the soils subjected to different mesotrione treatments corresponded to increases of 1.7-2.1, 1.1-1.6, and 1.7-2.5 times, respectively (compared to the control). Significant increases $(P<0.05)$ in substrate utilization were observed with a mesotrione concentration of $20 \mathrm{mg} \mathrm{kg}^{-1}$ for carbohydrate and amino acid, and $100 \mathrm{mg} \mathrm{kg}^{-1}$ for polymer and phenolic acid. However, there appeared a decrease in polymer, carboxylic, and acid amine by $3.0 \%, 12.5-17.1 \%$, and $13.3-48.1 \%$, respectively, in mesotrione treated soil of 50, 50-100, and $20-500 \mathrm{mg} \mathrm{kg}^{-1}$, respectively, and the amount of acid amine decreased sharply at a mesotrione content of $20 \mathrm{mg} \mathrm{kg}^{-1}(P<0.05)$.

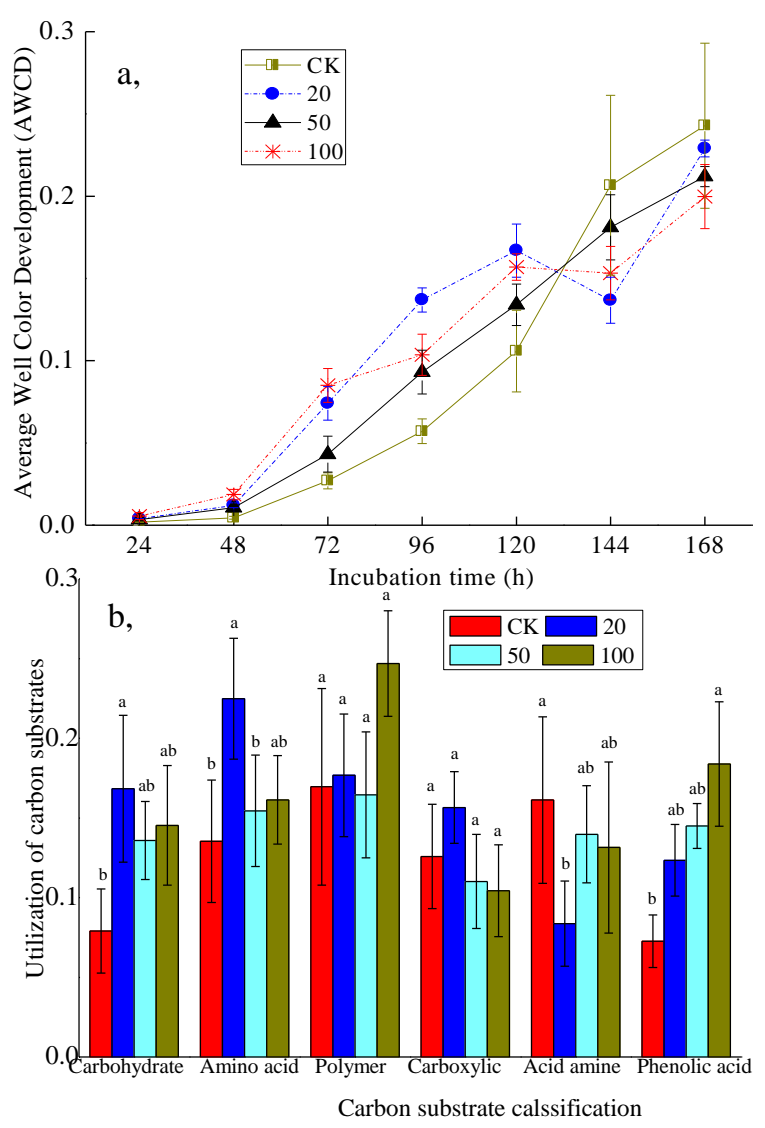

Figure 2. Microbial community level physiological profiles (CLPP) under different treatments of mesotrione. Note: (a) and (b) refers the variations in AWCD over time and utilization of 6 groups carbon sources, respectively

Principal component analysis (PCA) was used to assess the microbial communities in the stressed-soil environment (Kong et al., 2013; Shrestha et al., 2015). The PCA results from the Biolog Ecoplates data explained $67.3 \%$ of the total variance and components, and the first principal components (PC1) and the second principal components (PC2) accounted for $37.1 \%$ and $30.2 \%$, respectively (Fig. 3a). Therefore, the first two principal components ( $\mathrm{PC} 1$ and $\mathrm{PC} 2)$ were used to describe the effects of the different treatments of mesotrione $\left(0-200 \mathrm{mg} \mathrm{kg}^{-1}\right)$ on the utilization of 31 carbon sources. PC1 and PC2 are plotted against each other in Fig. 3 for illustration purposes. The PCA plots indicated that bacterial functional diversity changes with the level of mesotrione used. 
Most of the points were clustered in the first and second quadrants of the loading plot, and the plots amended with $20-100 \mathrm{mg} \mathrm{kg}^{-1}$ mesotrione were clustered together and are differentiated from the control. Fig. $3 b$ also compares the Biolog Ecoplates utilization patterns for each substrate guild (i.e. carbohydrate, amino acid, polymer, carboxylic, acid amine, and phenolic acid) for different mesotrione treatments, using PCA. The first variable (PC1) accounted for $54.8 \%$ and the second variable (PC2) accounted for $28.7 \%$ of the total variance in the data. Rotation of the matrix revealed that the substrate utilization can be separated into three groups: (a) amino acid and carboxylic (relatively negatively related with PC2), (b) carbohydrate and phenolic acid (positively associated with values of PC1 and PC2), and (c) polymer and acid amine (associated with negative values of PC1 and PC2). The PCA plots indicate that the bacterial communities originally present in the tested soil were shifted after application of mesotrione.
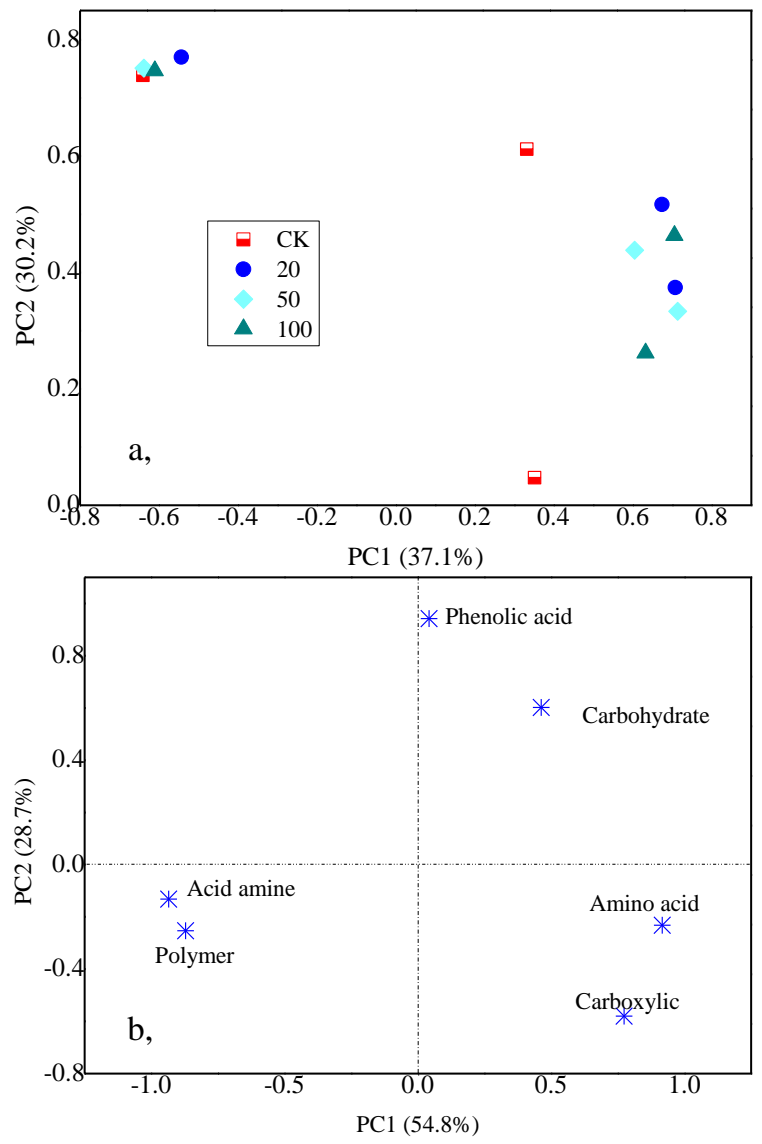

Figure 3. Scatterplots of principal components scores for soil samples based on (a) different treatments of mesotrione and (b) 6 carbon sources. Numbers in parentheses on axis labels is the percentage of the variation according to principal components analysis (PCA)

To further investigate the effect of mesotrione on the bacterial properties of the soil, the diversity indices of $H, D, E$, and $U$ are calculated to assess the soil's microbial functional diversity (Gomez et al., 2006), $H$ and $E$ values indicate the richness and evenness of the soil microorganisms (Zhou et al., 2008), index $D$ is often used to emphasize the dominant microbe population, and while $U$ (which is based on Euclidean distance) indicated the evenness or homogeneity of the microbial community (Zhou et 
al., 2008). The calculated values of the diversity indices of $H, D, E$, and $U$ are presented in Table 1 . In general, the $H, D$, and $U$ values gradually increased with incubation time and then fell. However, the amount of $H, D$, and $U$ was still 6.6-36.1\%, 2.0-12.2\%, and $70.1-894.0 \%$ greater than those of the control, respectively. Index $E$ decreased by $1.6-14.1 \%, 18.1-32.1 \%, 7.6-14.6 \%$, and $12.9-27.8 \%$, under mesotrione treatments of 0 , 20, 50, and $100 \mathrm{mg} \mathrm{kg}^{-1}$, respectively, when compared with the control. The microbial community analysis was consistent with substantial increases in microbe diversity in the treated soil. The $H, E, D$, and $U$ values were stimulated by the various mesotrione treatments, corresponding to increases of $2.7-3.4 \%, 1.3-10.2 \%, 1.4-2.2 \%$, and 6.6-20.0\%, respectively (compared to the control). The increase in the microbial activity in the soil may have been higher and the microorganisms more active if the mesotrione was used as an energy source (Crouzet et al., 2010; Zabaloy et al., 2010). The regression coefficients between the richness and Shannon-Weaver indices and organic carbon in the soil suggested that the increase in microbial community functional potential may be explained by the increase in carbon availability resulting from incorporation of the amendment (Gomez et al., 2006). The microorganism communities may have been indirectly stimulated by the dead biomass arising from more sensitive organisms together with a concomitant stimulation of the resistant microbial populations resulting from the loss of protozoan grazers or competitors (Crouzet et al., 2010). The number of live bacteria present was generally higher $(P<0.01)$ in linuron amended soil than in unamended soil (Grenni et al., 2009). However, there were no significant differences observed in the functional diversity parameters $H, E$, and $U$ among the different mesotrione treatments $(P>0.05)$.

Table 1. Diversity indices of Biolog in soils treated with mesotrione

\begin{tabular}{|c|c|c|c|c|c|c|c|c|c|}
\hline \multirow{2}{*}{$\begin{array}{c}\text { Diversity } \\
\text { indices }\end{array}$} & \multirow{2}{*}{\begin{tabular}{|c|}
$\begin{array}{c}\text { Mesotrione } \\
\left(\mathrm{mg} \mathrm{kg}^{-1}\right)\end{array}$ \\
\end{tabular}} & \multicolumn{7}{|c|}{ Time (h) } & \multirow{2}{*}{$\begin{array}{c}\text { Mean + } \\
\text { S.D. }\end{array}$} \\
\hline & & 24 & 48 & 72 & 96 & 120 & 144 & 168 & \\
\hline \multirow{5}{*}{$\begin{array}{r}\text { Shannon } \\
\text { index }(H)\end{array}$} & 0 & $1.94 \pm 0.08 \mathrm{c}$ & $2.61 \pm 0.17 \mathrm{a}$ & $2.56 \pm 0.15 \mathrm{a}$ & $2.65 \pm 0.11 \mathrm{a}$ & $2.63 \pm 0.10 \mathrm{a}$ & $2.64 \pm 0.07 \mathrm{a}$ & $2.64 \pm 0.11 \mathrm{a}$ & $2.52 \pm 0.26 \mathrm{a}$ \\
\hline & 20 & $2.37 \pm 0.01 \mathrm{a}$ & $2.94 \pm 0.12 \mathrm{a}$ & $2.53 \pm 0.12 \mathrm{a}$ & $2.57 \pm 0.10 \mathrm{a}$ & $2.59 \pm 0.09 \mathrm{a}$ & $2.55 \pm 0.07 \mathrm{a}$ & $2.71 \pm 0.05 \mathrm{a}$ & $2.61 \pm 0.18 \mathrm{a}$ \\
\hline & 50 & $2.15 \pm 0.11 b$ & $2.91 \pm 0.18 \mathrm{a}$ & $2.59 \pm 0.19 \mathrm{a}$ & $2.68 \pm 0.26 \mathrm{a}$ & $2.63 \pm 0.14 \mathrm{a}$ & $2.61 \pm 0.15 \mathrm{a}$ & $2.57 \pm 0.13 \mathrm{a}$ & $2.59 \pm 0.26 \mathrm{a}$ \\
\hline & 100 & $2.24 \pm 0.04 \mathrm{a}$ & $2.56 \pm 0.34 \mathrm{a}$ & $2.74 \pm 0.17 \mathrm{a}$ & $2.66 \pm 0.15 \mathrm{a}$ & $2.73 \pm 0.12 \mathrm{a}$ & $2.61 \pm 0.13 \mathrm{a}$ & $2.68 \pm 0.15 \mathrm{a}$ & $2.60 \pm 0.22 \mathrm{a}$ \\
\hline & & $P<0.01$ & $P>0.05$ & $P>0.05$ & $P>0.05$ & $P>0.05$ & $P>0.05$ & $P>0.05$ & $P>0.05$ \\
\hline \multirow{5}{*}{$\begin{array}{l}\text { Shannon } \\
\text { evenness } \\
\text { index }(E)\end{array}$} & 0 & $2.80 \pm 0.12 \mathrm{c}$ & $2.81 \pm 0.64 \mathrm{a}$ & $2.76 \pm 0.64$ & $2.41 \pm 0$. & $2.39 \pm 0.09 \mathrm{a}$ & $2.40 \pm 0.06 \mathrm{a}$ & $2.41 \pm$ & $2.57 \pm 0.36 \mathrm{~b}$ \\
\hline & 20 & $3.42 \pm 0.01 \mathrm{a}$ & $2.67 \pm 0.11 \mathrm{a}$ & $2.73 \pm 0.63$ & $2.78 \pm 0.68 \mathrm{a}$ & $2.80 \pm 0.69 \mathrm{a}$ & $2.32 \pm 0.06 \mathrm{a}$ & $2.47 \pm 0.05 \mathrm{a}$ & $2.74 \pm 0.49 \mathrm{ab}$ \\
\hline & 50 & $3.10 \pm 0.16 \mathrm{~b}$ & $2.65 \pm 0.17 \mathrm{a}$ & $2.79 \pm 0.59$ & $2.86 \pm 0.54 \mathrm{a}$ & $2.84 \pm 0.63 \mathrm{a}$ & $2.81 \pm 0.62 \mathrm{a}$ & $2.77 \pm 0.63 \mathrm{a}$ & $2.83 \pm 0.45 \mathrm{a}$ \\
\hline & 100 & $3.23 \pm 0.06 \mathrm{ab}$ & $2.33 \pm 0.31 \mathrm{a}$ & $2.49 \pm 0.15$ & $2.42 \pm 0.14 \mathrm{a}$ & $2.49 \pm 0.11 \mathrm{a}$ & $2.81 \pm 0.64 \mathrm{a}$ & $2.44 \pm 0.14 \mathrm{a}$ & $2.60 \pm 0.38 \mathrm{ab}$ \\
\hline & & $P<0.01$ & $P>0.05$ & $P>0.05$ & $P>0.05$ & $P>0.05$ & $P>0.05$ & $P>0.05$ & $P>0.05$ \\
\hline \multirow{5}{*}{$\begin{array}{c}\text { Simpson } \\
\text { index }(D)\end{array}$} & 0 & $0.81 \pm 0.02 \mathrm{~b}$ & $0.91 \pm 0.02 \mathrm{ab}$ & $0.86 \pm 0.04 \mathrm{~b}$ & $0.89 \pm 0.03 \mathrm{a}$ & $0.90 \pm 0.02 \mathrm{a}$ & $0.91 \pm 0.00 \mathrm{a}$ & $0.91 \pm 0.00 \mathrm{a}$ & $0.89 \pm 0.04 \mathrm{~b}$ \\
\hline & 20 & $0.89 \pm 0.00 \mathrm{a}$ & $0.94 \pm 0.00 \mathrm{a}$ & $0.90 \pm 0.00 \mathrm{a}$ & $0.91 \pm 0.01 \mathrm{a}$ & $0.91 \pm 0.00 \mathrm{a}$ & $0.88 \pm 0.02 b$ & $0.91 \pm 0.01 \mathrm{ab}$ & $0.90 \pm 0.02 \mathrm{a}$ \\
\hline & 50 & $0.87 \pm 0.01 \mathrm{a}$ & $0.94 \pm 0.00 \mathrm{a}$ & $0.90 \pm 0.00 \mathrm{a}$ & $0.91 \pm 0.02 \mathrm{a}$ & $0.91 \pm 0.00 \mathrm{a}$ & $0.90 \pm 0.01 \mathrm{a}$ & $0.89 \pm 0.01 \mathrm{~b}$ & $0.90 \pm 0.02 \mathrm{a}$ \\
\hline & 100 & $0.87 \pm 0.11 \mathrm{a}$ & $0.87 \pm 0.05 b$ & $0.91 \pm 0.01 \mathrm{a}$ & $0.91 \pm 0.01 \mathrm{a}$ & $0.92 \pm 0.01 \mathrm{a}$ & $0.90 \pm 0.01 \mathrm{ab}$ & $0.90 \pm 0.01 \mathrm{ab}$ & $0.90 \pm 0.03 \mathrm{ab}$ \\
\hline & & $P<0.01$ & $P<0.05$ & $P<0.05$ & $P>0.05$ & $P>0.05$ & $P<0.05$ & $P>0.05$ & $P<0.05$ \\
\hline \multirow{5}{*}{$\begin{array}{l}\text { McIntosh } \\
\text { index }(U)\end{array}$} & 0 & $0.02 \pm 0.00 \mathrm{~b}$ & $0.04 \pm 0.00 \mathrm{~b}$ & $0.32 \pm 0.09 \mathrm{~b}$ & $0.59 \pm 0.14 \mathrm{c}$ & $1.03 \pm 0.31 \mathrm{~b}$ & $1.92 \pm 0.05 \mathrm{a}$ & $2.22 \pm 0.47 \mathrm{a}$ & $0.88 \pm 0.88 \mathrm{a}$ \\
\hline & 20 & $0.04 \pm 0.00 \mathrm{ab}$ & $0.09 \pm 0.01 b$ & $0.72 \pm 0.11 \mathrm{a}$ & $1.27 \pm 0.11 \mathrm{a}$ & $1.59 \pm 0.17 \mathrm{a}$ & $1.47 \pm 0.25 \mathrm{a}$ & $2.17 \pm 0.11 \mathrm{sa}$ & $1.05 \pm 0.76 \mathrm{a}$ \\
\hline & 50 & $0.04 \pm 0.00 \mathrm{~b}$ & $0.08 \pm 0.01 b$ & $0.42 \pm 0.12 b$ & $0.85 \pm 0.19 \mathrm{bc}$ & $1.25 \pm 0.10 \mathrm{ab}$ & $1.74 \pm 0.13 \mathrm{a}$ & $2.16 \pm 0.10 \mathrm{a}$ & $0.93 \pm 0.79 \mathrm{a}$ \\
\hline & 100 & $0.06 \pm 0.03 \mathrm{a}$ & $0.21 \pm 0.07 \mathrm{a}$ & $0.78 \pm 0.14 \mathrm{a}$ & $0.97 \pm .17 \mathrm{~b}$ & $1.42 \pm 0.15 \mathrm{a}$ & $1.51 \pm 0.23 \mathrm{a}$ & $1.91 \pm 0.28 \mathrm{a}$ & $0.98 \pm 0.67 \mathrm{a}$ \\
\hline & & $P<0.05$ & $P<0.01$ & $P<0.01$ & $P<0.01$ & $P<0.05$ & $P>0.05$ & $P>0.05$ & $P>0.05$ \\
\hline
\end{tabular}

The same letters are not significantly at $P=0.05(\mathrm{n}=3)$ between different treatments of mesotrione according to the LSD test 


\section{Effect of mesotrione on microbial community structure diversity}

The changes in the bacterial structures of the tested soils were elucidated according to PCR-DGGE phylotype. The $H$ and $D$ indices were calculated to estimate the bacterial diversities in the mesotrione-amended and control soils (Table 2). The value of $H$ increased after different amounts of mesotrione were applied to the soil, being $0.7-3.6 \%$ higher than the $H$ value of the control group. However, differences in the $D$ index were negligible for the different mesotrione treatments. This indicated the stimulation effect or toxicity of the mesotrione on the soil microbial community was small (Hu et al., 2007).

Table 2. Diversity indices of DGGE in soils treated with mesotrione

\begin{tabular}{c|c|c}
\hline Treatment of mesotrione $\left(\mathbf{m g ~ k g}^{-\mathbf{1}}\right)$ & Shannon index $(\boldsymbol{H})$ & Shannon evenness index $(\boldsymbol{E})$ \\
\hline 0 & $3.02 \pm 0.78$ & $0.93 \pm 0.13$ \\
20 & $3.13 \pm 1.02$ & $0.96 \pm 0.24$ \\
50 & $3.04 \pm 0.81$ & $0.95 \pm 0.34$ \\
100 & $3.12 \pm 0.93$ & $0.95 \pm 0.29$ \\
\hline
\end{tabular}

The bacterial DGGE profiles generated using universal bacterial primers (F357 and R518) revealed the structural compositions of the communities in the soil samples (Fig. 4a). The results showed that there are certain differences in the bacterial community diversities in the soils - some bands disappeared and several new bands appeared - following mesotrione application. The disappearance of bands A and B revealed that the bacterial community structures and genetic diversity were affected by the increase in mesotrione concentration. It appeared that the number of bands is related to the mesotrione content. Nine bands (labeled a-i in Fig. 4a) were shared in all profiles. This suggested that the bacterial groups represented by these bands may play an important role in mesotrione ecology ( $\mathrm{Gu}$ et al., 2010). However, the number of bands in the soil samples initially increased with increasing mesotrione content, and then decreased slightly. Significant increases in microbial biomass were found afterwards (compared to the biomass values in unamended soil) in all cases. The microbial biomass was thus significantly increased. Moreover, the similarity indices decreased with increasing mesotrione content (varying from $68.0 \%$ to $47.6 \%$ ). Similarly, the maximum dissimilarity in the bacterial and fungal genetic structures between the control and 100-fold field rate (FR) treated soil did not exceed $12 \%$ and $28 \%$, respectively (Crouzet et al., 2010). This may be due to excessive stimulation of cellular redox processes which reflects an unspecified stress response of the microorganisms in the soil.

Clustering of the DGGE profiles was performed (to elucidate the similarities among the different banding patterns) and the results presented using a dendrogram (Zhang and Fang, 2000). The advantage of this method of presentation was that the coherence in the fingerprinting patterns can be rapidly assessed (Fromin et al., 2002). It can be seen that the $20-100 \mathrm{mg} \mathrm{kg}^{-1}$ mesotrione treatments belong to a common cluster which had a similarity among them of over $60 \%$, and $53 \%$ difference with the control group profiles (Fig. 4a). This showed that the bacterial communities in the soil changed upon addition of herbicide. El Fantroussi et al. (1999) compared the microbial communities in soil treated with three phenylurea herbicides (diuron, linuron, and chlorotoluron) using cluster analysis. They found that the microbial communities were significantly different compared to untreated soil. 

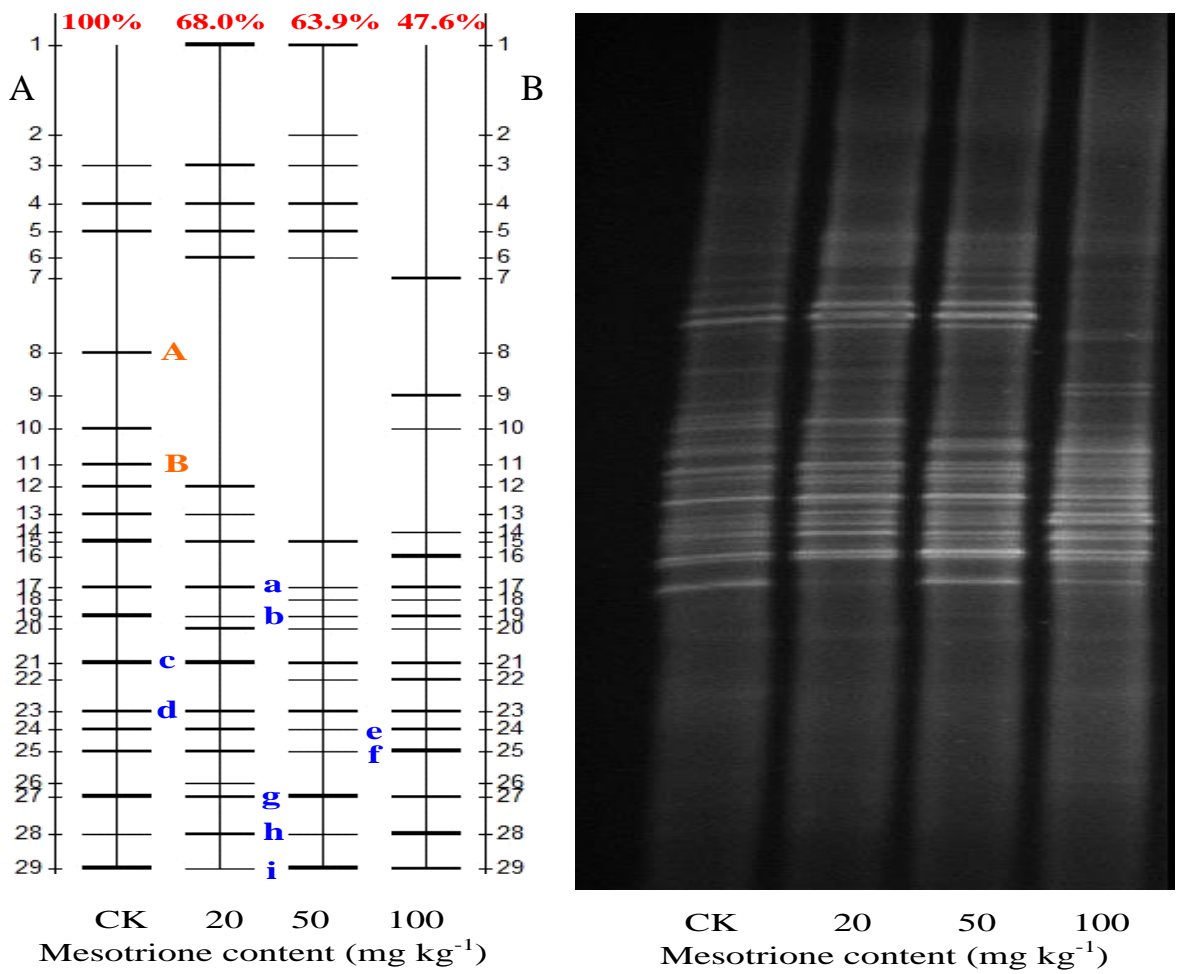

Figure 4. Comparison of bacterial communities between the control and the three treatments. Note: (A) the analysis results of lane comparison from the DGGE gels using Quantity One V4 4.0.0 software, and (B) DGGE profiles for PCR-amplified fragments of 16 sDNA. A, B, and a-i refer the bands of bacterial DGGE profiles

To obtain insight into the identities of the major bacterial populations, the discernible DGGE bands in the different mesotrione-treated samples (Fig. 4b) were all excised and used for nucleotide sequence analysis. Then, a BLAST search was conducted using the GenBank database to determine their phylogenetic types (Table 3). The sequences from bands a, c, and d were found to be closely related to members of the genus Desulfitobacterium $s p$. These are sulfate-reducing bacteria that can grow using meta-chlorinated benzoic acids as electron acceptors and are known to dechlorinate chlorinated phenols and other chlorinated compounds (Yoshida et al., 2007; Jing et al., 2013). The 16S rDNA of the isolated band b closely matched that of Herbaspirillum sp. $(98 \%)$. Bacteria of this genus fall into the $\beta$-Proteobacteria class and include known nitrogen-fixing endophytes (Doty et al., 2009) and can enhance the phytoremediation of volatile organics and herbicides (Ryan et al., 2008). Band e can be identified (99\%) with Burkholderia caledonica which had been found to degrade compounds such as herbicides (Hunter and Shaner, 2012), pentachlorophenols (Caliz et al., 2011), and a variety of aromatic hydrocarbons (Stopnisek et al., 2015). Band f showed 100\% sequence similarity to a taxonomically unidentified bacterium. Bands $\mathrm{g}$ and $\mathrm{h}$ were identical to those from strains Bacillus subterraneus and Clostridium sp., with $100 \%$ similarity. This also showed the capacity of these strains to acclimatize to organic compound pollution. The $16 \mathrm{~S}$ rDNA sequences of band i were $100 \%$ similar to the $16 \mathrm{~S}$ rDNA sequences of Bacillus sp. These bacteria commonly occurred in mesotrione-treated soil and was able to completely and rapidly biotransform mesotrione (Batisson et al., 2009). Biodegradation assays showed that only the Bacillus sp. strain 
was able to completely and rapidly bio-transform mesotrione (Durand et al., 2006a, 2006b; Batisson et al., 2009). This is because of the bacterial reductase that is involved in the enzymatic step in which the nitro group of mesotrione is reduced to an hydroxylamine moiety during the degradation process (Durand et al., 2010).

Table 3. Sequence analysis of bands excised from DGGE gels derived from bacterial $16 S$ rDNA fragments

\begin{tabular}{c|c|c|c}
\hline Band & Closest organisms in the GenBank database & Accession no. & Similarity (\%) \\
\hline a & Desulfitobacterium sp. & AB596883.1 & 99 \\
b & Herbaspirillum sp. & AB769218.1 & 98 \\
c & Desulfitobacterium sp. & AB596883.1 & 98 \\
d & Desulfitobacterium sp. & KB596883.1 & 97 \\
e & Kurkholderia caledonica & KM153196.1 & 99 \\
f & Uncultured bacterium & LN774202.1 & 100 \\
g & Bacillus subterraneus & JQ420069.1 & 100 \\
h & Clostridium sp. & KJ769178.1 & 100 \\
i & Bacillus sp. & \\
\hline
\end{tabular}

\section{Conclusions}

The results described in this study show that the treatment of soil with mesotrione was able to stimulate $7.5-92.5 \%$ and $27.1-44.4 \%$ increase for catalase and invertase activity, while urease activity was inhibited by 11.9-23.2\%. CLPPs were obtained that reflect the increase in the amount and rate of carbon utilization of carbohydrate, amino acid polymer and phenolic acid observed in soil subjected to different mesotrione treatments. In contrast, the AWCD of carboxylic and acid amine was inhibited after the application of $50-100 \mathrm{mg} \mathrm{kg}^{-1}$ and $20-100 \mathrm{mg} \mathrm{kg}^{-1}$ mesotrione, and principal component analysis plots showed that microbial function diversity changed with mesotrione level and each substrate guild. The resulting diversity indices $(H, D, E$, and $U$ ) indicate that mesotrione-treated soil had a greater number of more active microorganisms. Our DGGE analysis showed that mesotrione caused slight changes to be made to the biodiversity of the soil bacteria. However, the appearance of some new bands in the DGGE profiles suggests that mesotrione treatment does not have significantly toxic effects on the soil function. In future, it would be useful if further research on the impact of mesotrione could be more integrated with the farming procedures employed, especially herbicide continuous and extensive use. This should provide a more comprehensive understanding of the response of the microbial community in the soil.

Acknowledgements. This work was supported by the National Natural Science Foundation of China (21107056; 31971525) and the Central Public Research Institutes Basic Funds for Research and Development.

\section{REFERENCES}

[1] Allegrini, M., Zabaloy, M. C., Gómez, E. D. V. (2015): Ecotoxicological assessment of soil microbial community tolerance to glyphosate. - Science of The Total Environment 533: 60-68.

[2] Armel, G. R., Wilson, H. P., Richardson, R. J., Hines, T. E. (2009): Mesotrione Combinations in No-Till Corn (Zea mays). - Weed Technology 17(1): 111-116. 
[3] Baćmaga, M., Kucharski, J., Wyszkowska, J., Borowik, A., Tomkiel, M. (2014): Responses of microorganisms and enzymes to soil contamination with metazachlor. Environmental Earth Sciences 72: 2251-2262.

[4] Batisson, I., Crouzet, O., Besse-Hoggan, P., Sancelme, M., Mangot, J. F., Mallet, C., Bohatier, J. (2009): Isolation and characterization of mesotrione-degrading Bacillus sp. from soil. - Environmental Pollution 157: 1195-1201.

[5] Bhattacharyya, P., Tripathy, S., Kim, K., Kim, S. H. (2008): Arsenic fractions and enzyme activities in arsenic-contaminated soils by groundwater irrigation in West Bengal. - Ecotoxicology and Environmental Safety 71: 149-156.

[6] Cai, Z. Q., Li, S. S., Zhang, W. J., Ma, J. T., Wang, J., Cai, J. Y., Yang, G. H. (2015): Effects of the novel pyrimidynyloxybenzoic herbicide ZJ0273 on enzyme activities, microorganisms and its degradation in Chinese soils. - Environmental Science and Pollution Research 22: 4425-4433.

[7] Caliz, J., Vila, X., Martí, E., Sierra, J., Cruañas, R., Garau, M. A., Montserrat, M. (2011): Impact of chlorophenols on microbiota of an unpolluted acidic soil: microbial resistance and biodegradation. - FEMS Microbiology Ecology 78: 150-164.

[8] Cang, L., Zhou, D. M., Wang, Q. Y., Wu, D. Y. (2009): Effects of electrokinetic treatment of a heavy metal contaminated soil on soil enzyme activities. - Journal of Hazardous Materials 172: 1602-1607.

[9] Chen, Q. L., Wang, H., Yang, B. S., He, F. (2014): The combined effects of atrazine and lead $(\mathrm{Pb})$ : Relative microbial activities and herbicide dissipation. - Ecotoxicology and Environmental Safety 102: 93-99.

[10] Ciarkowska, K., Sołek-Podwika, K., Wieczorek, J. (2014): Enzyme activity as an indicator of soil-rehabilitation processes at a zinc and lead ore mining and processing area. - Journal of environmental management 132: 250-256.

[11] Crouzet, O., Batisson, I., Besse-Hoggan, P., Bonnemoy, F., Bardot, C., Poly, F., Bohatier, J., Mallet, C. (2010): Response of soil microbial communities to the herbicide mesotrione: a dose-effect microcosm approach. - Soil Biology and Biochemistry 42: 193202.

[12] Crouzet, O., Wiszniowski, J., Donnadieu, F., Bonnemoy, F., Bohatier, J., Mallet, C. (2013): Dose-dependent effects of the herbicide mesotrione on soil cyanobacterial communities. - Archives of Environmental Contamination and Toxicology 64: 23-31.

[13] Cycoń, M., Markowicz, A., Piotrowska-Seget, Z. (2013a): Structural and functional diversity of bacterial community in soil treated with the herbicide napropamide estimated by the DGGE, CLPP and r/K-strategy approaches. - Applied Soil Ecology 72: 242-250.

[14] Cycoń, M., Wójcik, M., Borymski, S., Piotrowska-Seget, Z. (2013b): Short-term effects of the herbicide napropamide on the activity and structure of the soil microbial community assessed by the multi-approach analysis. - Applied Soil Ecology 66: 8-18.

[15] Doty, S. L., Oakley, B., Xin, G., Kang, J. W., Singleton, G., Khan, Z., Vajzovic, A., Staley, J. T. (2009): Diazotrophic endophytes of native black cottonwood and willow. Symbiosis 47: 23-33.

[16] Durand, S., Amato, P., Sancelme, M., Delort, A. M., Combourieu, B., Besse-Hoggan, P. (2006a): First isolation and characterization of a bacterial strain that biotransforms the herbicide mesotrione. - Letters in Applied Microbiology 43: 222-228.

[17] Durand, S., Legeret, B., Martin, A. S., Sancelme, M., Delort, A. M., Besse-Hoggan, P., Combourieu, B. (2006b): Biotransformation of the triketone herbicide mesotrione by a Bacillus strain. Metabolite profiling using liquid chromatography/electrospray ionization quadrupole time-of-flight mass spectrometry. - Rapid Communications in Mass Spectrometry 20: 2603-2613.

[18] Durand, S., Sancelme, M., Besse-Hoggan, P., Combourieu, B. (2010): Biodegradation pathway of mesotrione: complementarities of NMR, LC-NMR and LC-MS for qualitative and quantitative metabolic profiling. - Chemosphere 81: 372-380. 
[19] El Fantroussi, S., Verschuere, L., Verstraete, W., Top, E. M. (1999): Effect of phenylurea herbicides on soil microbial communities estimated by analysis of 16S rRNA gene fingerprints and community-level physiological profiles. - Applied and Environmental Microbiology 65: 982-988.

[20] Floch, C., Chevremont, A. C., Joanico, K., Capowiez, Y., Criquet, S. (2011): Indicators of pesticide contamination: soil enzyme compared to functional diversity of bacterial communities via Biolog ${ }^{\circledR}$ Ecoplates. - European Journal of Soil Biology 47: 256-263.

[21] Fromin, N., Hamelin, J., Tarnawski, S., Roesti, D., Jourdain-Miserez, K., Forestier, N., Teyssier-Cuvelle, S., Gillet, F., Aragno, M., Rossi, P. (2002): Statistical analysis of denaturing gel electrophoresis (DGE) fingerprinting patterns. - Environmental Microbiology 4: 634-643.

[22] Giacometti, C., Cavani, L., Baldoni, G., Ciavatta, C., Marzadori, C., Kandeler, E. (2014): Microplate-scale fluorometric soil enzyme assays as tools to assess soil quality in a longterm agricultural field experiment. - Applied Soil Ecology 75: 80-85.

[23] Gomez, E., Ferreras, L., Toresani, S. (2006): Soil bacterial functional diversity as influenced by organic amendment application. - Bioresource Technology 97: 1484-1489.

[24] Grenni, P., Caracciolo, A. B., Rodríguez-Cruz, M., Sánchez-Martín, M. (2009): Changes in the microbial activity in a soil amended with oak and pine residues and treated with linuron herbicide. - Applied Soil Ecology 41: 2-7.

[25] Gryta, A., Frąc, M., Oszust, K. (2014): The application of the Biolog Ecoplate approach in ecotoxicological evaluation of dairy sewage sludge. - Applied biochemistry and biotechnology 174: 1434-1443.

[26] Gu, L. K., Bai, Z. H., Jin, B., Hu, Q. L., Wang, H. L., Zhuang, G. Q., Zhang, H. X. (2010): Assessing the impact of fungicide enostroburin application on bacterial community in wheat phyllosphere. - Journal of Environmental Sciences 22: 134-141.

[27] Hu, Q., Qi, H. Y., Zeng, J. H., Zhang, H. X. (2007): Bacterial diversity in soils around a lead and zinc mine. - Journal of Environmental Sciences 19: 74-79.

[28] Hu, J. L., Lin, X. G., Wang, J. H., Dai, J., Chen, R. R., Zhang, J. B., Wong, M. H. (2011): Microbial functional diversity, metabolic quotient, and invertase activity of a sandy loam soil as affected by long-term application of organic amendment and mineral fertilizer. Journal of Soils and Sediments 11: 271-280.

[29] Hua, F., Yu, Y. L., Chu, X. Q., Wang, X. G., Yang, X. E., Yu, J. Q. (2009): Degradation of chlorpyrifos in laboratory soil and its impact on soil microbial functional diversity. Journal of Environmental Sciences 21: 380-386.

[30] Hua, G., Chen, G. F., Lv, Z. P., Hua, Z., Hong, Y. (2009): Alteration of microbial properties and community structure in soils exposed to napropamide. - Journal of Environmental Sciences 21: 494-502.

[31] Huang, A. Q., Chen, H., Ling, C., Dai, Y. L., Zhao, J. F. (2008): Effects of Cd (II) and Cu (II) on microbial characteristics in 2-chlorophenol-degradation anaerobic bioreactors. Journal of Environmental Sciences 20: 745-752.

[32] Hunter, W. J., Shaner, D. L. (2012): Removing hexazinone from groundwater with microbial bioreactors. - Current microbiology 64: 405-411.

[33] Jacobsen, C. S., Hjelmsø, M. H. (2014): Agricultural soils, pesticides and microbial diversity. - Current Opinion in Biotechnology 27: 15-20.

[34] Jing, Z. Q., Hu, Y., Niu, Q. G., Liu, Y. Y., Li, Y. Y., Wang, X. C. (2013): UASB performance and electron competition between methane-producing archaea and sulfatereducing bacteria in treating sulfate-rich wastewater containing ethanol and acetate. Bioresource Technology 137: 349-357.

[35] Johnsen, K., Jacobsen, C. S., Torsvik, V., Sørensen, J. (2001): Pesticide effects on bacterial diversity in agricultural soils-a review. - Biology and Fertility of Soils 33: 443453. 
[36] Kandeler, E., Luxhøi, J., Tscherko, D., Magid, J. (1999): Xylanase, invertase and protease at the soil-litter interface of a loamy sand. - Soil Biology and Biochemistry 31: 11711179.

[37] Kong, X., Wang, C., Ji, M. (2013): Analysis of microbial metabolic characteristics in mesophilic and thermophilic biofilters using Biolog plate technique. - Chemical Engineering Journal 230: 415-421.

[38] Liu, W., Liu, H. J., Liu, W. P. (2000): Influence of pesticide imidacloprid and its metabolites on catalase activity in soil. - China Environmental Science 20: 524-527.

[39] Liu, B., Li, Y. X., Zhang, X. L., Wang, J., Gao, M. (2015): Effects of chlortetracycline on soil microbial communities: Comparisons of enzyme activities to the functional diversity via Biolog EcoPlates ${ }^{\mathrm{TM}}$. - European Journal of Soil Biology 68: 69-76.

[40] Loranger-Merciris, G., Barthes, L., Gastine, A., Leadley, P. (2006): Rapid effects of plant species diversity and identity on soil microbial communities in experimental grassland ecosystems. - Soil Biology and Biochemistry 38: 2336-2343.

[41] Lupwayi, N. Z., Brandt, S. A., Harker, K. N., O’Donovan, J. T., Clayton, G. W., Turkington, T. K. (2010): Contrasting soil microbial responses to fertilizers and herbicides in a canola-barley rotation. - Soil Biology and Biochemistry 42: 1997-2004.

[42] Osem, Y., Chen, Y., Levinson, D., Hadar, Y. (2007): The effects of plant roots on microbial community structure in aerated wastewater-treatment reactors. - Ecological Engineering 29: 133-142.

[43] Pose-Juan, E., Sánchez-Martín, M. J., Herrero-Hernández, E., Rodríguez-Cruz, M. S. (2015): Application of mesotrione at different doses in an amended soil: Dissipation and effect on the soil microbial biomass and activity. - Science of The Total Environment 536: 31-38.

[44] Qing, H., Qi, H. Y., Zeng, J. H., Zhang, H. X. (2007): Bacterial diversity in soils around a lead and zinc mine. - Journal of Environmental Sciences 19: 74-79.

[45] Raju, M. N., Venkateswarlu, K. (2014): Effect of repeated applications of buprofezin and acephate on soil cellulases, amylase, and invertase. - Environmental Monitoring and Assessment 186: 6319-6325.

[46] Ryan, R. P., Germaine, K., Franks, A., Ryan, D. J., Dowling, D. N. (2008): Bacterial endophytes: recent developments and applications. - FEMS Microbiology Letters 278: 19.

[47] Shrestha, K., Stevens, S., Shrestha, P., Adetutu, E. M., Walsh, K. B., Ball, A. S., Midmore, D. J. (2015): Characterisation of the soil microbial community of cultivated and uncultivated vertisol in Australia under several management regimes. - Agriculture, Ecosystems \& Environment 199: 418-427.

[48] Stopnisek, N., Zühlke, D., Carlier, A., Barberán, A., Fierer, N., Becher, D., Riedel, K., Eberl, L., Weisskopf, L. (2015): Molecular mechanisms underlying the close association between soil Burkholderia and fungi. - The ISME Journal 10(1): 253-264.

[49] Sukul, P. (2006): Enzymatic activities and microbial biomass in soil as influenced by metalaxyl residues. - Soil Biology and Biochemistry 38: 320-326.

[50] Sun, Y. B., Sun, G. H., Xu, Y. M., Wang, L., Liang, X. F., Lin, D. S. (2013a): Assessment of sepiolite for immobilization of cadmium-contaminated soils. - Geoderma 193: 149-155.

[51] Sun, Y. B., Xu, Y. M., Sun, Y., Qin, X., Wang, Q. (2013b): Dissipation and dynamics of mesotrione in maize and soil under field ecosystem. - Bulletin of Environmental Contamination and Toxicology 90: 242-247.

[52] Sun, Y. B., Li, Y., Xu, Y. M., Liang, X. F., Wang, L. (2015): In situ stabilization remediation of cadmium $(\mathrm{Cd})$ and lead $(\mathrm{Pb})$ co-contaminated paddy soil using bentonite. - Applied Clay Science 105: 200-206.

[53] Sun, Y. B., Xu, Y. M., Sun, Y., Qin, X. (2015): Adsorption-desorption characteristics of mesotrione in phaiozem and red soils. - Environmental Chemistry 34: 1832-1838. 
[54] Vyn, J. D., Swanton, C. J., Weaver, S. E., Sikkema, P. H. (2006): Control of Amaranthus tuberculatus var. rudis (common waterhemp) with pre and post-emergence herbicides in Zea mays L. (maize). - Crop Protection 25: 1051-1056.

[55] Xu, J., Zhang, Y., Dong, F. S., Liu, X. G., Wu, X. H., Zheng, Y. Q. (2014): Effects of repeated applications of chlorimuron-ethyl on the soil microbial biomass, activity and microbial community in the greenhouse. - Bulletin of Environmental Contamination and Toxicology 92: 175-182.

[56] Yao, X. H., Min, H., Lü, Z. H., Yuan, H. P. (2006): Influence of acetamiprid on soil enzymatic activities and respiration. - European Journal of Soil Biology 42: 120-126.

[57] Ye, Y. F., Min, H., Zhou, X. C. (2003): Effects of mefenacet on microbial respiration and enzyme activities in paddy soil. - Acta Pedologica Sinica 41: 93-96.

[58] Yoshida, N., Yoshida, Y., Handa, Y., Kim, H. K., Ichihara, S., Katayama, A. (2007): Polyphasic characterization of a PCP-to-phenol dechlorinating microbial community enriched from paddy soil. - Science of The Total Environment 381: 233-242.

[59] Zabaloy, M. C., Garland, J. L., Gomez, M. A. (2010): Assessment of the impact of 2, 4dichlorophenoxyacetic acid (2, 4-D) on indigenous herbicide-degrading bacteria and microbial community function in an agricultural soil. - Applied Soil Ecology 46: 240246.

[60] Zhang, T., Fang, H. P. (2000): Digitization of DGGE (denaturing gradient gel electrophoresis) profile and cluster analysis of microbial communities. - Biotechnology Letters 22: 399-405.

[61] Zhang, C. P., Liu, X. G., Dong, F. S., Xu, J., Zheng, Y. Q., Li, J. (2010): Soil microbial communities response to herbicide 2, 4-dichlorophenoxyacetic acid butyl ester. European Journal of Soil Biology 46: 175-180.

[62] Zhang, W., Zhang, M., An, S., Xiong, B., Li, H., Cui, C. Z., Lin, K. F. (2012): Ecotoxicological effects of decabromodiphenyl ether and cadmium contamination on soil microbes and enzymes. - Ecotoxicology and Environmental Safety 82: 71-79.

[63] Zhou, J., Guo, W. H., Wang, R. Q., Han, X. M., Qiang, W. (2008): Microbial community diversity in the profile of an agricultural soil in northern China. - Journal of Environmental Sciences 20: 981-988. 